\title{
Metabolic and IL-6-Induced Inflammatory Responses in High-Intensity Intermittent Exercise among Type 2 Diabetes Patients with Sarcopenia
}

\author{
Zhenchao Liu', Feifei Xia1, Xinbo Zhao², Donghao Zhou ${ }^{2}$ \\ ${ }^{1}$ Institute of Integrative Medicine, Medical College, Qingdao University, Qingdao, China \\ ${ }^{2}$ Qingdao University Eleventh Hospital (Linyi People's Hospital), Qingdao, China \\ Email: hanfangyixue@126.com
}

How to cite this paper: Liu, Z.C., Xia, F.F., Zhao, X.B. and Zhou, D.H. (2018) Metabolic and IL-6-Induced Inflammatory Responses in High-Intensity Intermittent Exercise among Type 2 Diabetes Patients with Sarcopenia. Open Access Library Journal, 5: e4622.

https://doi.org/10.4236/oalib.1104622

Received: April 25, 2018

Accepted: May 20, 2018

Published: May 23, 2018

Copyright $\odot 2018$ by authors and Open Access Library Inc.

This work is licensed under the Creative Commons Attribution International License (CC BY 4.0).

http://creativecommons.org/licenses/by/4.0/

\section{(c) (i) Open Access}

\begin{abstract}
Objective: The aim of this study was to examine the effects of high-intensity intermittent exercise (HIIE) on features of immunometabolism by comparing elderly female sarcopenia and non-sarcopenia in elderly female patients with type 2 diabetes (T2MD). Differences in metabolism and inflammatory responses between the two groups were compared. Methods: 6 elderly female sarcopenia patients with T2MD served as sarcopenia group, and 7 elderly female non-sarcopenia patients with T2MD served as control subjects. Using dual energy X-ray absorptiometry (DXA) to the subjects' body fat compositions was measured. All subjects underwent three high-intensity Wingate tests at 5-minute intervals, and peak and average power during each Wingate trial were recorded. Blood samples were collected immediately after the test was completed. Peripheral blood levels of the inflammatory cytokine IL-6, which is related to mitosis, were measured in both groups before and after HIIE by ELISA. Results: The non-sarcopenia group had a higher metabolic rate than the sarcopenia group. Sarcopenia had no significant effect on the differences in the IL-6 inflammatory response $(p=0.430)$. Conclusion: The metabolic energy and rate during HIIE differed between the two groups. Non-sarcopenia group exhibited higher metabolic levels. No significant difference between groups was observed in the IL-6 inflammatory response during HIIE.
\end{abstract}

\section{Subject Areas}

Diabetes \& Endocrinology 


\section{Keywords}

Sarcopenia, Type 2 Diabetes, IL-6

\section{1. はじめに}

高齢 2 型糖尿病者はサルコペニアになりやすく、その病症は筋肉量の减少、 筋力及び体力の低下、そして、転倒や骨折のリスクは健常者よりはるかに 高くなるので、2 型糖尿病患者の暮らしに支障が出ている。筋肉は体の运 动器官でもあり、代谢器官でもあるので、グルコースが代谢する主な场所 になり $[1]$ 、糖质の代谢に重要な调节机能を果たしている。先行研究による と、运动时に筋肉のグリコーゲンの分解能力は低下し [2]、その同时に筋肉 が攝取するグルコースの量は増え、细胞膜のグルコースの移転と细胞内の グルコースへの利用も多くなると报告される[3]。それだけではなく、筋肉 はインシュリン抵抗が一番早く现れる器官で、体全体のインシュリン抵抗 の进化にはとても重要である[4] [5]。そのほかに、筋肉は IL-6、IL-15、TNF-a などの细胞因子の运动による免疫の改善、炎症の反応や免疫调节にかかわ っているという研究もあったようである[6] [7] [8] [9]。それらの炎症因子、 たとえば IL-6 などはインシュリン抵抗の现れに密接な关系を持っている [5] [10]。要するに、筋肉は运动器官でもあり、代谢器官でもあり、免疫器 官でもあるので、代谢や免疫において重要な役割を果たし、2 型糖尿病と 密接な相关をもっている。

高强度间欠的运动(HIIE)は短时间で行う全力的で、爆発的なハイスピー ドの运动で、代谢の出発物质の有効性とエネルギーの相互作用を伴ってい る[11]。HIIE や高强度间欠的训练(HIIT)に关する先行研究は主にスポーツ 选手あるいは一般人を対象として行われたが[11] [12] [13] [14] [15]、2 型糖 尿病、高血圧、心臓血管疾患などの慢性疾患に关する研究の多くはHIIE ま たはHIITによっての介入治疗研究で[16] [17] [18]、筋力への影响に关する 研究も含まれている[19]。これらの研究は慢性疾患の HIIE または HIIT の 研究にかかわっているが、慢性的な代谢疾患の筋肉量によって异なる HIIE の免疫代谢についての研究がまだ発表されていない。したがって、本研究 の目的は筋肉量が异なる 2 型糖尿病の高齢の女性患者が行う高强度间欠的 运动の免疫代谢(immunometabolism)の特性を评価することである。

\section{2. 対象と研究方法}

対象

2017 年 8 月から 11 月までに青岛大学付属第十一病院で诊疗を受けた 6 名の サルコペニアの高齢 2 型糖尿病女性(平均年齢は $69.33 \pm 7.89$ 岁)を本研究の サルコペニア群の対象にした一方で、同时期の 7 名の 2 型糖尿病非サルコ ペニアの高齢の女性患者(平均年齢は $70.43 \pm 7.66$ 岁)を非サルコペニア群の 対象にした。本研究は青岛大学付属病院の伦理审査を通り、対象に说明を 行った(承认番号: QYFY2017025)。すべての対象は自主的に本研究に关与 
した。すべての対象に対象群に入ってからの一周间に一同の饮食と休悪を し、毎日中等度〜高强度の运动を実施しないように指示した。

1）诊断の基准: サルコペニアの诊断の基准は Asian working group for sarcopenia (AWGS)の基准にしたがい[20]、步行の速度は $0.8 \mathrm{~m} / \mathrm{s}$ 以下で、女 性の场合は、握力は $18 \mathrm{~kg}$ 以下で、筋肉量の $S M I$ 指标は $5.40 \mathrm{~kg} / \mathrm{m}^{2}$ である。

2) 付け加えの基准: a) 60 歳以上の 2 型糖尿病の女性患者 b) サルコペニ アの诊断の基准に合う 2 型糖尿病の高齡の女性患者(サルコペニア群）c） SMI 指标が正常な 2 型糖尿病患者(非サルコペニア群)。

3）対象外になる基准: a) ほかの持病を合并している女性患者 b) 60 歳以 下の女性患者 c) SMI 低下であるが、握力や步行の速度が正常な女性患者 d) サルコペニアに副作用を与えるホルモン关连の薬物を长期的に饮む女性患 者e）身体障害があるあるいは病状が深刻な女性患者。

\section{3. 研究方法}

\section{1. 筋肉量の测定}

二重エネルギーX 线吸収法(DXA)で骨量を含めない除脂肪量を测定した (Lunar Prodigy; GE; USA)。すべての対象に金属制の饰り物を外し、平常な 室温でベッドに横になり、両足を揃え、体を両手に挟むょうに指示し、二 重エネルギーX 线吸収を测定した。测定终了后、脂肪を除いた四肢の软组 织量を采取し、脂肪を除いた四肢の软组织量を身长の二乗で除すことによ り、筋肉量指标 SMI を算出した, $S M I=$ 四肢除去脂肪软组织量 $(A M M) /$ 身 长 $\left(\mathrm{m}^{2}\right)[20]$ 。

\section{2. 握力と歩行速度の测定}

握力测りで握力计を测定した(CAMRY; EH101; China)。测定は左右各二回ず つ実施し、その平均值を解析值とした。歩行速度の测定で 6 メートルの歩 行実験を行った。対象に普段の歩行の速度で 6 メートルの距离を歩くょう に指示し、ストップウォッチで歩く时间を记録し、2 回の歩行时间の平均 值を歩行速度の值にした。

\section{3. 高强度の间欠的な Wingate Test}

Wingate test は无酸素性エネルギ一供给能力を评価している。受験者は $2-4$ $\min$ の准备动作后、休息 $3-5 \mathrm{~min}$ 、运动开始に、最大努力でペダル回転数 をあげ、30 秒间すべて全力で维持するょうに指示する[21]。実験前の $24 \mathrm{~h}$ 间に中等度〜高强度の运动を実施しないように指示し、朝食を捸取する前 に高强度の间欠的な Wingate test $5 \mathrm{~min}$ の休息を挟み、三回行った。テス トの前、対象に室内のロードバイクに乗り、15 min のウォーミングアップ のうちに全力でハイスピードの漕ぎを二回し、それに心拍数が 150 拍 $/ \mathrm{min}$ に达するように、その漕ぎを毎回 $8 \mathrm{~s}$ まで続けるように指示した。 5 分间の 休息で心拍数が 100 拍/min に下がったら、自転车エルゴメーターというダ イナモメーターで実験を行うょうにした(Monark; 828E; Sweden)。始まった 直后の $30 \mathrm{~s}$ 以内に対象にできるだけ早くロードバイクを漕ぎ、そのうちに 漕ぎ姿を变えないように指示した。それから、対象が全力を出すように励 
ました。ピークパワーと平均パワーを记録した。そして、 5 min の休息を挟 み、そのような Wingate test を三回缲り返した。途中で具合が悪くなった対 象がいたら、すぐにテストを中止するょうにした。

\section{4. サンプルの测定}

1) 乳酸の测定:テストの前と毎回の Wingate test 终了の $1 \mathrm{~min}$ 后に対象の 耳の先の血液をサンプルとして采取し、Accutrend Plus で血中乳酸量(LA) を测定した(Roche; Germany)。数值は mmol/l で示されている。

2) 血糖の测定: テストの前と三回の Wingate test 终了后に対象の上腕部 周りの静脉の血液を采取し、全自动生物化学分析器(日立; 7080; Japan)で 血糖の测定を行った。

3) IL-6 の测定: テストの前と三回の Wingatetest 终了后に対象の上腕部周 りの静脉の血液を采取し、ELISA 法で静脉の血清の细胞因子 IL-6 を测定し た(BIOSH; SUB10377; China)。

\section{5. 统计学の方法}

Spss21.0 でデータを统计し、Shapiro-Wilk でデータの正规分布を検证した。 サルコペニア群と非サルコペニア群の关连项目の平均值の差の比较は $\mathrm{t}$ 検 定を用いたが、HIIE の关连项目の比较はマッチング $\mathrm{t}$ 検定で行われた。要 因がピークパワーや平均パワー、IL-6、血中乳酸量、血糖の变化への影响 を 2 要因反复测定分散分析で分析し、Mauchly 球形検定で各变数が対称に なるかどうかを検证し、必要な时に Greenhouse-Geisser で订正した。分散 の标准偏差を Bonferroni で検证した。また、 $\eta^{2} て ゙$ 効果を算出した。 $p<0.05$ の场合しか统计学的な意味がないと考えられる。

\section{4. 结果}

2 つの群の基本状况は表 1 から见ると、サルコペニア有症群の $\operatorname{SMI}(t=$ $-6.905, p<0.001)$ 、筋肉量 $(t=-3.649, p=0.004)$ と握力 $(t=-3.484, p=0.007)$ が着しく低下した。

高强度间欠的运动の间に、サルコペニアの影响 $\left(\mathrm{F}_{1,11}=7.05, p=0.022, \eta^{2}=\right.$ $0.39)$ おびテスト试合の効果 $\left(\mathrm{F}_{2,22}=191.40, p<0.001, \eta^{2}=0.95\right)$ にピークパ ワーに対する试験试行の効果があったが、交互作用を示さなかった $\left(\mathrm{F}_{2,22}=\right.$ $\left.0.06, p=0.837, \eta^{2}=0.01\right)$ 。表 2 から见て、非サルコペニア有症群と比较して みれば、サルコペニア有症群のピークパワーが着しく低下した $(p=0.022 ;$ $95 \% \mathrm{CI}=15.643-167.088)$ 。サルコペニア有症群の 1 回目は 2 回目よりピー クパワーが高く $(p<0.001 ; 95 \% \mathrm{CI}=63.51-102.15) 、 3$ 回目よりもピークパワ 一が高いが $(p<0.001 ; 95 \% \mathrm{CI}=106.80-175.87) 、 2$ 回目は 3 回目よりもピー クパワーが高い $(p<0.001 ; 95 \% \mathrm{CI}=37.38-79.62)$ 。非サルコペニア有症群の 1 回目は 2 回目よりピークパワーが高い $(p<0.001 ; 95 \% \mathrm{CI}=64.77$ - 105.80)、 3 回目よりもピークパワーが高いが $(p<0.001 ; 95 \% \mathrm{CI}=104.10-173.33) 、 2$ 回目は 3 回目よりもピークパワーが高い $(p=0.001 ; 95 \% \mathrm{CI}=38.12-68.74)$ 。

高强度间欠的运动の间に、サルコペニアの影响 $\left(\mathrm{F}_{1,11}=6.18, p=0.030, \eta^{2}=\right.$ $0.36)$ およびテスト试合の効果 $\left(\mathrm{F}_{2,22}=226.67, p<0.001, \eta^{2}=0.95\right)$ に平均パワ 
Table 1. Initial indexes in the two groups of patients $(\bar{x} \pm s)$.

\begin{tabular}{ccccc}
\hline & sarcopenia & non-sarcopenia & $t$ & $p$ \\
\hline Age (year) & $69.33 \pm 7.89$ & $70.43 \pm 7.66$ & -0.254 & 0.805 \\
Medical history (year) & $9.50 \pm 3.45$ & $9.29 \pm 3.82$ & 0.105 & 0.918 \\
SMI (kg/m $)$ & $4.62 \pm 0.66^{*}$ & $6.73 \pm 0.44$ & -6.905 & $<0.001$ \\
muscle mass (kg) & $30.39 \pm 7.03^{*}$ & $42.03 \pm 4.36$ & -3.649 & 0.004 \\
Grip (kg) & $12.33 \pm 2.25^{*}$ & $21.00 \pm 2.83$ & -3.484 & 0.007 \\
\hline
\end{tabular}

${ }^{*}$ Compared with the non-sarcopenia group, $p<0.05$.

Table 2. Peak power and average power during three wingate tests in the two groups of patients $(\bar{x} \pm s)$.

\begin{tabular}{lcc}
\hline & sarcopenia & non-sarcopenia \\
\hline The peak power for the 1 st time of wingate test(W) & $424.83 \pm 63.46^{\mathrm{abc}}$ & $516.14 \pm 78.66^{\mathrm{bc}}$ \\
The peak power for the 2 nd time of wingate test(W) & $342.00 \pm 54.49^{\mathrm{ac}}$ & $430.86 \pm 65.65^{\mathrm{c}}$ \\
The peak power for the $3 \mathrm{rd}$ time of wingate test(W) & $283.50 \pm 54.81^{\mathrm{a}}$ & $377.43 \pm 58.58$ \\
The average power for the 1 st time of wingate test(W) & $299.83 \pm 57.17^{\mathrm{abc}}$ & $376.00 \pm 57.95^{\mathrm{bc}}$ \\
The average power for the 2 nd time of wingate test(W) & $228.33 \pm 52.27^{\mathrm{ac}}$ & $300.14 \pm 61.55^{\mathrm{c}}$ \\
The average power for the $3 \mathrm{rd}$ time of wingate test(W) & $171.33 \pm 51.92^{\mathrm{a}}$ & $254.43 \pm 59.19$ \\
\hline
\end{tabular}

${ }^{\text {aSignificant difference compared with the non-sarcopenia group, } p<0.05 \text {; }{ }^{\mathrm{b}} \text { Significant difference compared }}$ with the second Wingate test, $p<0.05$; 'Significant difference compared with the third Wingate test, $p<$ 0.05 .

一に対する试験试行の効果があったが、交互作用を示さなかった $\left(\mathrm{F}_{2,22}=\right.$ $\left.0.63, p=0.465, \eta^{2}=0.04\right)$ 。表 2 から见て、非サルコペニア有症群と比较して みれば、サルコペニア有症群の平均パワーが着しく低下した $(p=0.022 ; 95 \%$ $\mathrm{CI}=-151.67--14.52)$ 。サコペニア有症群の 1 回目は 2 回目ょりも平均パ ワーが高く $(p<0.001 ; 95 \% \mathrm{CI}=50.71-92.29) 、 3$ 回目よりも平均パワーが高 いが $(p<0.001 ; 95 \% \mathrm{CI}=109.88-147.12) 、 2$ 回目は 3 回目よりも平均パワー が高い $(p=0.006 ; 95 \% \mathrm{CI}=25.16$ - 88.84)。非サルコペニア有症群の 1 回目は 2 回目よりも平均パワーが高く $(p<0.001 ; 95 \% \mathrm{CI}=53.75$ - 97.97)、3 回目よ りも平均パワーが高いが $(p<0.001 ; 95 \% \mathrm{CI}=103.62-139.53) 、 2$ 回目は 3 回 目よりも平均パワーが高い $(p<0.001 ; 95 \% \mathrm{CI}=33.58-57.85)$ 。

高強度間欠的運動の間に、サルコペニアの影響 $\left(\mathrm{F}_{1,11}=6.16 ; p=0.030 ; \eta^{2}=\right.$ $0.36)$ およびテスト試合の効果 $\left(\mathrm{F}_{3,33}=281.16 ; p<0.001 ; \eta^{2}=0.96\right)$ に乳酸值に 対する試験試行の効果があったが、交互作用を示さなかった $\left(\mathrm{F}_{3,33}=3.22 ; P=\right.$ $\left.0.035 ; \eta^{2}=0.23\right)$ 。表 3 から見て、非サルコペニア有症群と比較してみれば、 サルコペニア有症群の乳酸值が著しく低下した $(p=0.030 ; 95 \% \mathrm{CI}=0.125$ 2.095)。サルコペニア有症群の 3 回目の乳酸值は 2 回目ょりもが高く $(P=$ $0.001 ; 95 \% \mathrm{CI}=0.86-1.71) 、 1$ 回目ょりも高く $(P<0.001 ; 95 \% \mathrm{CI}=3.04-$ 4.56)、初期值よりも高いが $(P<0.001 ; 95 \% \mathrm{CI}=6.66-9.81) 、 2$ 回目の乳酸值 は 1 回目より高く $(P<0.001 ; 95 \% \mathrm{CI}=1.91-3.12)$ 、初期值よりもが高い $(p<$ $0.001 ; 95 \% \mathrm{CI}=5.61-8.29)$ 。 1 回目の乳酸值は初期值よりも高い $(p<0.001$; $95 \% \mathrm{CI}=2.88-5.98)$ 。非サルコペニア有症群の 3 回目の乳酸值は 2 回目より 
Table 3. Blood lactic acid results before and after the three wingate tests in the patients in the two groups $(\bar{x} \pm s)$.

\begin{tabular}{ccc}
\hline & sarcopenia & non-sarcopenia \\
\hline Blood lactic acid volume before HIIE (mmol/l) & $1.40 \pm 0.20^{\text {bcd }}$ & $1.47 \pm 0.36^{\text {bcd }}$ \\
Blood lactic acid volume for the 1st time of wingate test $(\mathrm{mmol} / \mathrm{l})$ & $5.83 \pm 1.43^{\text {cd }}$ & $6.60 \pm 1.24^{\text {cd }}$ \\
Blood lactic acid volume for the 2nd time of wingate test (mmol/l) & $8.35 \pm 1.22^{\text {ad }}$ & $9.91 \pm 1.14^{\mathrm{d}}$ \\
Blood lactic acid volume for the 3rd time of wingate test $(\mathrm{mmol} / \mathrm{l})$ & $9.63 \pm 1.49^{\mathrm{a}}$ & $11.67 \pm 1.05$ \\
\hline
\end{tabular}

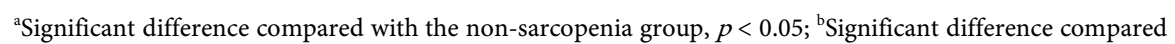
with the first Wingate test, $p<0.05$; 'Significant difference compared with the second Wingate test, $p<$ 0.05 ; ${ }^{\mathrm{d} S i g n i f i c a n t}$ difference compared with the third Wingate test, $p<0.05$.

Table 4. Blood glucose results before and after the three wingate tests in the patients in the two groups $(\bar{x} \pm s)$.

\begin{tabular}{ccc}
\hline & sarcopenia & non-sarcopenia \\
\hline Blood glucose volume before HIIE $(\mathrm{mmol} / \mathrm{l})$ & $8.23 \pm 0.48^{\mathrm{b}}$ & $8.57 \pm 0.68^{\mathrm{b}}$ \\
Blood glucose volume after HIIE $(\mathrm{mmol} / \mathrm{l})$ & $9.53 \pm 0.81^{\mathrm{a}}$ & $10.57 \pm 0.54$ \\
\hline
\end{tabular}

${ }^{\mathrm{a} S i g n i f i c a n t}$ difference compared with the non-sarcopenia group, $p<0.05$; ${ }^{\mathrm{b}}$ Significant difference compared with the after HIIE, $p<0.05$.

も高く $(p=0.001 ; 95 \% \mathrm{CI}=1.02-2.50) 、 1$ 回目ょりも高く $(p<0.001 ; 95 \% \mathrm{CI}=$ 3.59 - 6.55)、初期值よりも高いが $(p<0.001 ; 95 \% \mathrm{CI}=8.95$ - 11.45)、2 回目の 乳酸值は 1 回目よりもが高い $(p<0.001 ; 95 \% \mathrm{CI}=2.16-4.47) 、 2$ 回目の乳酸 值は初期值よりもが高い $(p<0.001 ; 95 \% \mathrm{CI}=7.12-9.77)$ 。 1 回目の乳酸值は 初期值よりも高い $(p<0.001 ; 95 \% \mathrm{CI}=3.79$ - 6.47)。

高強度間欠的運動の間に、サルコペニアの影響 $\left(\mathrm{F}_{1,11}=5.30 ; p=0.042 ; \eta^{2}=\right.$ $0.33)$ およびモーメントの効果 $\left(\mathrm{F}_{1,11}=73.86 ; p<0.001 ; \eta^{2}=0.87\right)$ に血糖值に対 する試験試行の効果があったが、交互作用を示さなかった $\left(\mathrm{F}_{1,11}=3.32 ; p=\right.$ 0.096; $\left.\eta^{2}=0.23\right)$ 。ルコペニア有症群の血糖值の变化が著しい(8.23 \pm 0.48 $\mathrm{mmol} / \mathrm{l} \mathrm{VS} 9.53 \pm 0.81 \mathrm{mmol} / \mathrm{l}) 、(p=0.001 ; 95 \% \mathrm{CI}=-1.73--0.87)$ 。非サルコ ペニア有症群の血糖值の変化が著しい $(8.57 \pm 0.68 \mathrm{mmol} / \mathrm{l}$ VS $10.57 \pm 0.54$ $\mathrm{mmol} / \mathrm{l}) 、(p=0.001,95 \% \mathrm{CI}=-2.79--1.21)($ 表 4$)$ 。

ただし、高強度間欠的運動の間に、モーメントの効果 $\left(\mathrm{F}_{1,11}=23.55 ; p=\right.$ 0.001; $\eta^{2}=0.68$ に IL-6 值に対する試験試行の効果があったが.サルコペニア の影響 $\left(\mathrm{F}_{1,11}=0.67 ; p=0.430 ; \eta^{2}=0.06\right)$ および交互作用 $\left(\mathrm{F}_{1,11}=1.37 ; p=0.266\right.$; $\left.\eta^{2}=0.11\right)$ を示さなかった。图 1 から見ると、サルコペニア有症群の IL-6 值 の変化が著しい $(30.98 \pm 7.68 \mathrm{pg} / \mathrm{ml} \mathrm{VS} 34.68 \pm 9.33 \mathrm{pg} / \mathrm{ml}),(p=0.006,95 \% \mathrm{CI}=$ $-5.78--1.62)$ 。非サルコペニア有症群の IL-6 值の変化が著しい $(26.39 \pm 5.97$ $\mathrm{pg} / \mathrm{ml}$ VS $32.44 \pm 7.77 \mathrm{pg} / \mathrm{ml}),(p=0.012,95 \% \mathrm{CI}=-10.26--1.85)$ (图 1)。

\section{5. 考察}

筋肉は運動機能を持つだけではなく、化学エネルギーが機械エネルギーや 熱エネルギーに転換する場所である。また、エネルギ一の貯蔵、消費や転 換及び体の新陳代謝や生命活動など重要なことに関係している。したがっ て、2 型糖尿病になっても、筋肉は代謝のバランスの維持やエネルギーの 


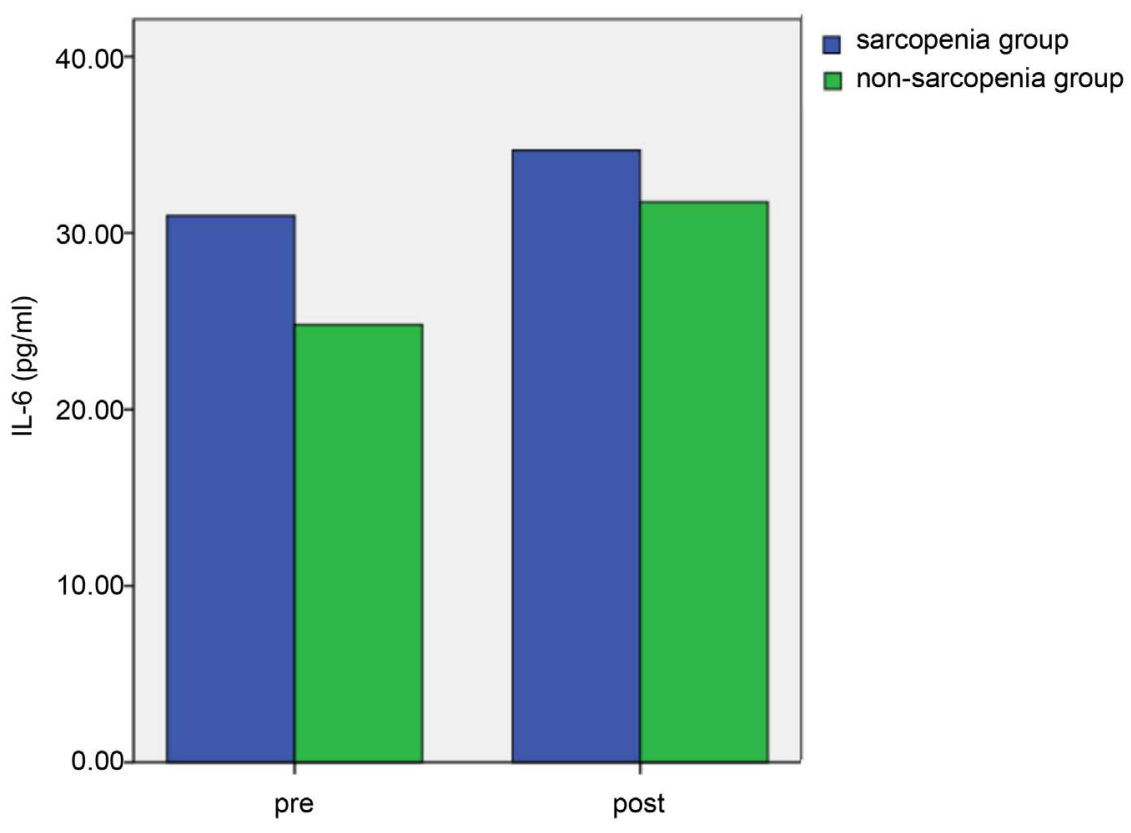

Figure 1. IL-6 levels before and after HIIE.

保存に役立つと推測される。先行研究では、サルコペニアになると IL-6が 上がるということが報告されている[22]。IL-6 は筋肉の蛋白質の合成を妨 げ、蛋白質の分解に直接に関与するので、筋肉量の減少につながっている [22]。それから、四肢の筋力の低下に大いにかかわっている[23] [24]。それ によって、IL-6 はインシュリン抵抗と関係があるばかりではなく、サルコ ペニアにもかかわっていると見られる。先行研究では、筋肉が運動時に IL-6 を大量に分泌するのは筋肉の収縮が IL-6 の遺伝子を活性化したことと関係 していると示されている[25] [26]。一方で、shigemoto など[27]によると、 サルコペニアは運動神経の細胞を減少させ、筋力の低下になると報告され ている。しだがって、筋力の低下は患者の運動時の筋力の収縮力と速度を ょり低くし、IL-6 の遺伝子をょり速く活性化させないので、IL-6 の反応を 弱めたと推測される。だから、本研究は最初にサルコペニアの高齢 2 型糖 尿病女性の HIIE のエネルギ一代謝状況と炎症細胞因子 IL-6 の変化が 2 型 糖尿病非サルコペニアの高齢の女性患者より低いという仮説を想定した。

本研究では、サルコペニア群や非サルコペニア群の代謝状況は明らかに 差があり(血中乳酸や血糖における)、HIIEになった 2 型糖尿病非サルコペ ニアの高齢の女性患者がょり高く代謝レベルを保ち、HIIE のピークパワー や平均パワーがサルコペニアの高齢 2 型糖尿病女性よりはるかに高いと考 えられる。Wingate test のピークパワーや平均パワーはそれぞれ ATP-CP シ ステムや解糖系のエネルギーの供給状況を評価することになった。運動時 に筋肉の収縮を維持するために、筋肉が捸取するグルコ一スの量が増える ので[28]、サルコペニア患者と比べると、筋肉量がょり多い高齡 2 型糖尿病 女性に必要なグルコースがょり多く求められ、より高い代謝のレベルにな れると考えられる。Wingate testについての最近の研究では、下肢の筋肉量 と嫌気代謝は正の相関関係を示していると報告された[29]ので、サルコペニ 
アは 2 型糖尿病の高齢の女性患者の代謝レベルの低下につながっていると 考えられる。

運動時に IL-6 が急速にエネルギ一基質の利用率を高め、体の活動量と時 間の長さによって变わっていくと発見された[11]。これらの研究のによっ て、本研究は最初、サルコペニアが IL-6 の反応を弱め、IL-6 が運動時の工 ネルギー基質への調整機能も低下するという仮説を行った。Meyer など[30] は一回きりと繰り返しの短時間の無酸素運動についての研究では、IL-6 が 運動後に増えると推測した。Gökbel など[31]は青年の男子を対象とした Wingate テストによって血漿の IL-6 が増えると示した。それに、Febbraio など [25]も 2 型糖尿病患者を対象としたロードバイク漕ぎの 25 分間テスト を通して IL-6 の増加が明らかだと発見した。本研究において、対象が HIIE になってから、IL-6 も大いに増加すると考えられる。そういう点が先行研 究と一致したのだ。本研究では、サルコペニア群と非サルコペニア群の代 謝レベルの差が示されたけれども、IL-6 の差については、時間の長さが原 因の一つだと判明されたが、サルコペニアの影響が判明されなかった。つ まり、サルコペニアは IL-6の炎症反応に直接な関係を持っていないという ことである。本研究ではサルコペニア群の対象は運動前に IL-6 の数が非サ ルコペニア群より高いが、サルコペニア患者の IL-6についての先行研究ほ ぞそんなに差が出ていない。それは 2 型糖尿病患者自身が IL-6の異常を起 こさせたからと推測された。IL-6はサルコペニアにかかわっているだけで はなく、インシュリン抵抗を分泌する重要な炎症細胞因子である。Febbraio など[25]によると、2 型糖尿病患者の運動が誘発する IL-6 の形成は健常者よ り強まる傾向があると報告されている。けれども、サルコペニア患者と 2 型糖尿病サルコペニア患者の病症が類似していると報告される研究がまだ 見つからない。したがって、サルコペニアと IL-6 の関係が 2 型糖尿病患者 の代謝に影響するメカニズムがあるかどうかをはっきりさせるために、よ り深く研究を進めていかなければならない。

本研究はいくつかの限界を含んでいる。まず、サンプルの数が比較的に 少ない。また、エネルギ一基質と炎症細胞因子がより多く本研究に取り入 れられなかった。さらに、運動はサルコペニアに大きい影響を及ぼすので、 対象の普段の体の活動量を参考として研究に取り入れることも有意義なこ とである。だから、これからそういう点について研究を続けていくと考え られる。要するに、本研究ではサルコペニア群と非サルコペニア群の IL-6 炎症反応は大きな差が出ていないと考えられる。

\section{6. 結論}

1）サルコペニアは 2 型糖尿病の高齢の女性患者の代謝レベルの低下につ ながっている。

2) 2 型糖尿病の高齢の女性患者に対して、サルコペニア群と非サルコペ ニア群の IL-6 炎症反応は大きな差が出ていない。

\section{利益相反自己申告}

申告すべきものはなし。 


\section{References}

[1] Jue, T., Rothman, D.L., Shulman, G.I., Tavitian, B.A., DeFronzo, R.A. and Shulman R.G. (1989) Direct Observation of Glycogen Synthesis in Human Muscle with 13C NMR. Proceedings of the National Academy of Sciences of the United States of America, 86, 4489-4491. https://doi.org/10.1073/pnas.86.12.4489

[2] Richter, E.A., Sonne, B., Christensen, N.J. and Galbo, H. (1981) Role of Epinephrine for Muscular Glycogenolysis and Pancreatic Hormonal Secretion in Running Rats. American Journal of Physiology, 240, E526-E532. https://doi.org/10.1152/ajpendo.1981.240.5.E526

[3] Rose, A.J. and Richter, E.A. (2005) Skeletal Muscle Glucose Uptake during Exercise: How Is It Regulated? Physiology, 20, 260-270. https://doi.org/10.1152/physiol.00012.2005

[4] Onamb, G.L., Pearson, X. and Breen, L. (2006) Wide Clinical Implementation of Insulin Resistance Syndrome? Metabolic Syndrome \& Related Disorders, 4, 165-171. https://doi.org/10.1089/met.2006.4.165

[5] Pillon, N.J., Bilan, P.J., Fink, L.N. and Klip, A. (2013) Cross-Talk between Skeletal Muscle and Immune Cells: Muscle-Derived Mediators and Metabolic Implications. American Journal of Physiology Endocrinology \& Metabolism, 304, E453-E465. https://doi.org/10.1152/ajpendo.00553.2012

[6] Ostrowski, K., Rohde, T., Asp, S., Schjerling, P. and Pedersen, B.K. (2001) Chemokines Are Elevated in Plasma after Strenuous Exercise in Humans. European Journal of Applied Physiology, 84, 244-245. https://doi.org/10.1007/s004210170012

[7] Ostrowski, K., Rohde, T., Zacho, M., Asp, S. and Pedersen, B.K. (2010) Evidence that Interleukin-6 Is Produced in Human Skeletal Muscle during Prolonged Running. Journal of Physiology, 508, 949-953. https://doi.org/10.1111/j.1469-7793.1998.949bp.x

[8] Molanouri Shamsi, M., Hassan, Z.M., Quinn, L.S., Gharakhanlou, R., Baghersad, L. and Mahdavi, M. (2015) Time Course of IL-15 Expression after Acute Resistance exercise in Trained Rats: Effect of Diabetes and Skeletal Muscle Phenotype. Endocrine, 49, 396-403. https://doi.org/10.1007/s12020-014-0501-x

[9] Steensberg, A., Keller, C., Starkie, R.L., Osada, T. and Febbraio, M.A. (2002) Pedersen BK.IL-6 and TNF-Alpha expRession in, and Release from, Contracting Human Skeletal Muscle. American Journal of Physiology Endocrinology \& Metabolism, 283, E1272-1278. https://doi.org/10.1152/ajpendo.00255.2002

[10] Kim, T.H., Choi, S.E., Ha, E.S., Jung, J.G., Han, S.J., Kim, H.J., Kim, D.J., Kang, Y. and Lee, K.W. (2013) IL-6 Induction of TLR-4 Gene Expression via STAT3 Has an Effect on Insulin Resistance in Human Skeletal Muscle. Acta Diabetologica, 50, 189-200. https://doi.org/10.1007/s00592-011-0259-z

[11] Lira, F.S., Panissa, V.L., Julio, U.F. and Franchini, E. (2015) Differences in Metabolic and Inflammatory Responses in Lower and Upper Body High-Intensity Intermittent Exercise. European Journal of Applied Physiology, 115, 1467-1474. https://doi.org/10.1007/s00421-015-3127-7

[12] Astorino, T.A., Allen, R.P., Jurancich, M., Roberson, D.W. and Trost, E. (2010) Effect of High-intensity Interval Training (HIIT) on Cardiovascular Function and Muscular Force: 1027: June 4 3:15 PM - 3:30 PM. Medicine \& Science in Sports \& Exercise, 42, 138-139. https://doi.org/10.1249/01.MSS.0000386331.58054.8a

[13] Trapp, E.G., Chisholm, D.J., Freund, J. and Boutcher, S.H. (2008) The Effects of High-Intensity Intermittent Exercise Training on Fat Loss and Fasting Insulin Levels of Young Women. International Journal of Obesity, 32, 684-691. 
https://doi.org/10.1038/sj.ijo.0803781

[14] Sim, A.Y., Wallman, K.E., Fairchild, T.J. and Guelfi, K.J. (2015) Effects of High-Intensity Intermittent Exercise Training on Appetite Regulation. Medicine \& Science in Sports \& Exercise, 47, 2441-2449. https://doi.org/10.1249/MSS.0000000000000687

[15] Chuensiri, N., Tanaka, H. and Suksom, D. (2015) The Acute Effects of Supramaximal High-Intensity Intermittent Exercise on Vascular Function in Lean vs. Obese Prepubescent Boys. Pediatric Exercise Science, 27, 503-509. https://doi.org/10.1123/pes.2015-0100

[16] Terada, T., Friesen, A., Chahal, B.S., Bell, G.J., McCargar, L.J. and Boulé, N.G. (2013) Exploring the Variability in Acute Glycemic Responses to Exercise in Type 2 Diabetes. Journal of Diabetes Research, 2013, 1-6. https://doi.org/10.1155/2013/591574

[17] Krustrup, P., Randers, M.B., Andersen, L.J., Jackman, S.R., Bangsbo, J. and Hansen, P.R. (2013) Soccer Improves Fitness and Attenuates Cardiovascular Risk Factors in Hypertensive Men. Medicine \& Science in Sports \& Exercise, 45, 553-560. https://doi.org/10.1249/MSS.0b013e3182777051

[18] Cassidy, S., Thoma, C., Hallsworth, K., Parikh, J., Hollingsworth, K.G., Taylor, R., Jakovljevic, D.G. and Trenell, M.I. (2016) High Intensity Intermittent Exercise Improves Cardiac Structure and Function and Reduces Liver Fat in Patients with Type 2 Diabetes: A Randomised Controlled Trial. Diabetologia, 59, 56-66. https://doi.org/10.1007/s00125-015-3741-2

[19] Sculthorpe, N.F., Herbert, P. and Grace, F. (2017) One Session of High-Intensity Interval Training (HIIT) Every 5 Days, Improves Muscle Power But Not Static Balance in Lifelong Sedentary Ageing Men: A Randomized Controlled Trial. Medicine, 96, 1-8. https://doi.org/10.1097/MD.0000000000006040

[20] Chen, L.K., Liu, L.K., Woo, J., Assantachai, P., Auyeung, T.W., Bahyah K.S., Chou, M.Y., Chen, L.Y., Hsu, P.S., Krairit, O., Lee, J.S., Lee, W.J., Lee, Y., Liang, C.K., Limpawattana, P., Lin, C.S., Peng, L.N., Satake, S., Suzuki, T., Won, C.W., Wu, C.H., Wu, S.N., Zhang, T., Zeng, P., Akishita, M. and Arai, H. (2014) Sarcopenia in Asia: Consensus Report of the Asian Working Group for Sarcopenia. Journal of the American Medical Directors Association, 15, 95-101. https://doi.org/10.1016/j.jamda.2013.11.025

[21] Medbø, J.I. and Tabata, I. (1989) Relative Importance of Aerobic and Anaerobic Energy Release during Short-Lasting Exhausting Bicycle Exercise. Journal of Applied Physiology, 67, 1881-1886. https://doi.org/10.1152/jappl.1989.67.5.1881

[22] Bian, A.L., Hu, H.Y. and Rong, Y.D. (2017) A Study on Relationship between Elderly Sarcopenia and Inflammatory Factors IL-6 and TNF- $\alpha$. Maturitas, 22, 25. https://doi.org/10.1186/s40001-017-0266-9

[23] Pereira, L.S., Narciso, F.M., Oliveira, D.M., Coelho, F.M., Souza Dda G. and Dias, R.C. (2009) Correlation between Manual Muscle Strength and Interleukin-6 (IL-6) Plasma Levels in Elderly Community-Dwelling Women. Archives of Gerontology \& Geriatrics, 48, 313-316. https://doi.org/10.1016/j.archger.2008.02.012

[24] Stenholm, S., Maggio, M., Lauretani, F., Bandinelli, S., Ceda, G.P., Di Iorio, A., Giallauria, F., Guralnik, J.M. and Ferrucci, L. (2010) Anabolic and Catabolic Biomarkers as Predictors of Muscle Strength Decline: The InCHIANTI Study. Rejuvenation Research, 13, 3-11. https://doi.org/10.1089/rej.2009.0891

[25] Febbraio, M.A. and Pedersen, B.K. (2002) Muscle-Derived Interleukin-6: Mechanisms for Activation and Possible Biological Roles. The FASEB Journal, 16, 1335-1347. 
https://doi.org/10.1096/fj.01-0876rev

[26] Pedersen, B.K. and Fischer, C.P. (2007) Beneficial Health Effects of Exercise-The Role of IL-6 as a Myokine. Trends in Pharmacological Sciences, 28, 152-156. https://doi.org/10.1016/j.tips.2007.02.002

[27] Shigemoto, K., Mori, S., Fukunaga, T. and Miyazaki, T. (2013) Aging Research on Muscle and Motor Neuron. Japanese Journal of Geriatrics, 50, 349-351. https://doi.org/10.3143/geriatrics.50.349

[28] Richter, E.A., Kiens, B., Saltin, B., Christensen, N.J. and Savard, G. (1988) Skeletal Muscle Glucose Uptake during Dynamic Exercise in Humans: Role of Muscle Mass. American Journal of Physiology, 254, E555.

[29] Wang, L. and Wang, X.L. (2017) Study on Body Composition and Anaerobic Metabolism of Male Taekwondo Athletes in North University of China. Hubei Sports Science (China), 35, 869-872.

[30] Meyer, T., Gabriel, H.H., Rätz, M., Müller, H.J. and Kindermann, W. (2001) Anaerobic Exercise Induces Moderate Acute Phaseresponse. Medicine \& Science in Sports \& Exercise, 33, 549-555. https://doi.org/10.1097/00005768-200104000-00007

[31] Gökbel, H., Okudan, N., Gül, I., Belviranli, M., Gergerlioğlu, H.S. and Başaral, M.K. (2012) Effects of Repeated Bouts of Supramaximal Exercise on Plasma Adiponectin, Interleukin-6, and Tumor Necrosis Factor- $\alpha$ Levels in Sedentary Men. Journal of Strength \& Conditioning Research, 26, 1675-1679.

https://doi.org/10.1519/JSC.0b013e318231ac1c 